\title{
Distribution, status and conservation of a Critically Endangered, extremely narrow endemic: Lamyropsis microcephala (Asteraceae) in Sardinia
}

\author{
Giuseppe Fenu, Efisio Mattana and Gianluigi Bacchetta
}

\begin{abstract}
The aims of this work were to verify the distribution and population size of Lamyropsis microcephala (Asteraceae), characterize its habitat, assess its conservation status and initiate conservation measures for this Critically Endangered species. Distribution was determined by field surveys and mapping. To estimate population size and density 81 permanent monitoring plots were randomly established. Ex situ conservation measures were activated by harvesting and appropriate storage of seed. We confirmed the presence of $L$. microcephala at two previously known sites and found it in two previously unknown localities. The areas in which the species occur vary from 200 to $240,000 \mathrm{~m}^{2}$, at altitudes of $1,450-1,820 \mathrm{~m}$, on slopes of $15-45^{\circ}$ with aspects from north to west. The estimated number of ramets per population varied from c. 2,000 to $\mathrm{c}$. $2,000,000$, with a mean density of $8.29 \pm$ SD 14.3 to $10.33 \pm$ SD 10.05 ramets $\mathrm{m}^{-2}$. Our findings confirmed the Critically Endangered status of this species, although with different criteria. This study is an example of an integrated approach for the conservation of an extremely narrow endemic plant species and may be useful for other little-known threatened species for which urgent conservation measures are needed.
\end{abstract}

Keywords IUCN assessment, Lamyropsis microcephala, population size, Sardinia, seed-banking

\section{Introduction}

The Global Strategy for Plant Conservation (GSPC, 2008) and the European Plant Conservation Strategy (Planta Europa, 2008) aim to halt the continuing loss of plant diversity and, as part of this, the development of conservation strategies is an issue that needs to be urgently addressed at the national level (GSPC, 2008; Sharrock \& Jones, 2009). To develop a conservation strategy for a species, assessment of conservation status is the first step (Planta Europa, 2008) and the now accepted standard for doing this is the categories and criteria of the IUCN Red List of Threatened Species (IUCN, 2001; Grammont de \& Cuarón, 2006; Rodrigues et al., 2006; Hoffman et al., 2008).

Giuseppe Fenu (Corresponding author), Efisio Mattana and Gianluigi BACChETTA Centro Conservazione Biodiversità, Dipartimento di Scienze Botaniche-Università degli Studi di Cagliari. Viale S. Ignazio da Laconi, 1309123 Cagliari, Italy. E-mail gfenu@unica.it

Received 26 April 2010. Revision requested 14 June 2010.

Accepted 20 July 2010.
In situ conservation measures such as the protection and restoration of natural habitats are the best methods of preserving biological diversity (Lande, 1988; FranciscoOrtega et al., 2000). However, in urgent situations ex situ conservation becomes an alternative way to prevent immediate extinction. One of the most effective ways to conserve ex situ plant diversity is storage in a seed bank, which is the most practical method for preserving large amounts of genetic material in a small space and with minimum risk of genetic damage (Iriondo \& Pérez, 1999).

Within the Mediterranean biodiversity hotspot (Myers et al., 2000), central northern Sardinia, including the Gennargentu massif, has been identified as one of 52 putative glacial refugia (sensu Médail \& Diadema, 2009). The flora of this massif, however, has been little investigated. One of the elements of this flora is Lamyropsis microcephala (Moris) Dittrich \& Greuter (Family Asteraceae), a perennial rhizomatous herb endemic to an extremely restricted area on the north (Pisargiu, Fonni) and south-western (Rio Aratu, Desulo) slopes of Mount Bruncu Spina (Diana Corrias, 1977; Camarda, 2006; Bacchetta et al., 2007, 2008).

L. microcephala has been reported to have low seed set and low seed germination and to mainly propagate vegetatively (Diana Corrias, 1977). Based on seed germination requirements (i.e. pre-chilling and high germination temperatures) Mattana et al. (2009) demonstrated that L. microcephala is adapted to a temperate climate and suggested that its distribution is still contracting under the present Mediterranean climate. The two localities in which the species was previously known to occur, being isolated both ecologically and genetically, are considered separate populations (G. Bacchetta et al., unpubl. data).

Global warming is affecting the distribution of species (Iverson \& Prasad, 1998; Bakkenes et al., 2002), and particularly of endemic plants (Pickering et al., 2008), causing latitudinal and altitudinal shifts (Gottfried et al., 1999). Climatic variations can alter distribution areas and reduce population sizes and thus increase the risk of extinction of threatened species (Davis \& Shaw, 2001). In addition, warmer temperatures affect seed germination of mountain species such as L. microcephala (Mattana et al., 2009) that require a pre-chilling period to germinate (Kazakisv et al., 2007).

L. microcephala is considered one of the most threatened endemic plant species in Sardinia because of the negative 
effects of a ski run, built in the plant's habitat, and associated touristic activities (Arrigoni, 1974; Pignatti et al., 2001). The species is categorized as Critically Endangered on the National (Conti et al., 1992), Regional (Conti et al., 1997) and global Red Lists (Camarda, 2006), is one of the top 50 threatened plants species of the Mediterranean Islands (Montmollin de \& Strahm, 2005), and listed in Appendix I of the Bern Convention and as a priority species in Annex II of the European Habitats Directive (DIR 92/43/EEC). L. microcephala has recently been included on the European threatened plant list (Sharrock \& Jones, 2009) but no conservation actions, either in situ or ex situ, have been previously implemented (Camarda, 2006).

Considering the urgency of conservation action for L. microcephala and the lack of ecological and conservation studies on the endemic flora of the Gennargentu massif, the main aim of this study was to develop an in situ and ex situ conservation strategy for this Critically Endangered endemic species. We estimated the species' distribution and population size, characterized its habitat, identified threats, reassessed the species' conservation status and established ex situ conservation measures.

\section{Study area}

The c. 30,00o ha Gennargentu massif has a maximum altitude of $1,834 \mathrm{~m}$ and is characterized by several ridges higher than $1,500 \mathrm{~m}$. The bedrock consists of Paleozoic metamorphytes and granodiorites. Available climate data (from Fonni at $900 \mathrm{~m}$ ) indicates a typical Mediterranean annual pattern of temperature and precipitation, with a dry summer. Bioclimatically this area is classified as temperate sub-Mediterranean (Bacchetta et al., 2008).

\section{Methods}

The distribution of $L$. microcephala was verified by field surveys during 2006-2009 in the localities for which herbarium specimens (in the herbaria of CAG, Università degli Studi di Cagliari; CAT, Università di Catania; FI, Museo di Storia Naturale, Florence; SASSA, Università di Sassari (Faculty of Sciences); SS, Università di Sassari (Faculty of Pharmacy); TO, University of Turin; and in GBIF, 2011) and/or published data (Diana Corrias, 1977; Bacchetta et al., 2007, 2008) were available. When a locality was confirmed or discovered, the following studies were undertaken.

The geographical limits of localities were mapped each year, with a global positioning system, and areas estimated, using ArcView v. 3.2 (ESRI, Redlands, USA), to detect any annual changes in area occupied. For each locality we noted the altitudinal range, slope, aspect and habitat type according to the European Habitat Directive (DIR 92/43/EEC).

Eighty-one permanent plots of $2 \times 1 \mathrm{~m}$ were randomly established in each locality in 2009 to estimate ramet densities. We estimated the number of ramets per locality by counting the number in each plot and then extrapolating the mean density per plot to the whole area. All the ramets found in the plots were monitored monthly from July to September and the number of capitula per reproductive ramet determined in August. The non-parametric KruskalWallis test was used to analyse differences in density, and a one-way ANOVA used to examine mean number of capitula per ramet, followed by a post hoc Duncan's test to examine differences between group means. All statistical tests were performed using Statistica v. 6.o (Statsoft, Tulsa, USA).

The threats to L. microcephala in each locality were determined from field observations and categorized following the IUCN threats classification scheme (IUCN, 2010b). A grid of $2 \times 2 \mathrm{~km}$ was used for assessing area of occupancy (AOO, defined as the area within the extent of occurrence, EOO, that is occupied by a taxon, where EOO is defined as the area contained within the shortest continuous imaginary boundary that can be drawn to encompass all the known sites of occurrence of a taxon, excluding cases of vagrancy; IUCN, 2001), following IUCN (2008) and Rossi \& Gentili (2008). EOO and conservation status were assessed following IUCN (2008).

The conservation measures adopted or proposed for the species were based on our field observations and on published data (Diana Corrias, 1977; Camarda, 2006; Bacchetta et al., 2007, 2008) and reported following the IUCN Conservation Actions Classification Scheme (IUCN, 2010a). After obtaining the permits required by European and National laws we harvested seeds from all of the confirmed and newly discovered localities. Seeds were stored in the Sardinian Germplasm Bank (BG-SAR) where, once cleaned by removing the pappus and separating any empty aborted seeds, they were placed in a dry room at $15 \%$ relative humidity and $15^{\circ} \mathrm{C}$ and then at $5^{\circ} \mathrm{C}$ (the active collection) and at $-25^{\circ} \mathrm{C}$ (the base collection), the latter comprising a black-box collection (material stored for future use) and a check-up collection (seed lots for testing viability during storage). We also commenced an education and awareness programme with the local people and relevant authorities at the regional and local level, offering lectures and seminars to increase awareness of the importance of conserving threatened plant species.

\section{Results}

We confirmed the presence of $L$. microcephala in the two already known sites, at Rio Aratu and Pisargiu, both of them on the Bruncu Spina ridge, and found two new sites, at Bruncu Spina and Bau 'e Laccos (Fig. 1, Table 1). The area of the four localities varied from $200 \mathrm{~m}^{2}$ to $240,000 \mathrm{~m}^{2}$, at altitudes of $1,450-1,820 \mathrm{~m}$, on slopes of $15-45^{\circ}$ with north to west aspects, with the plants growing preferentially along catchment areas or in moderate hygrophilous conditions 


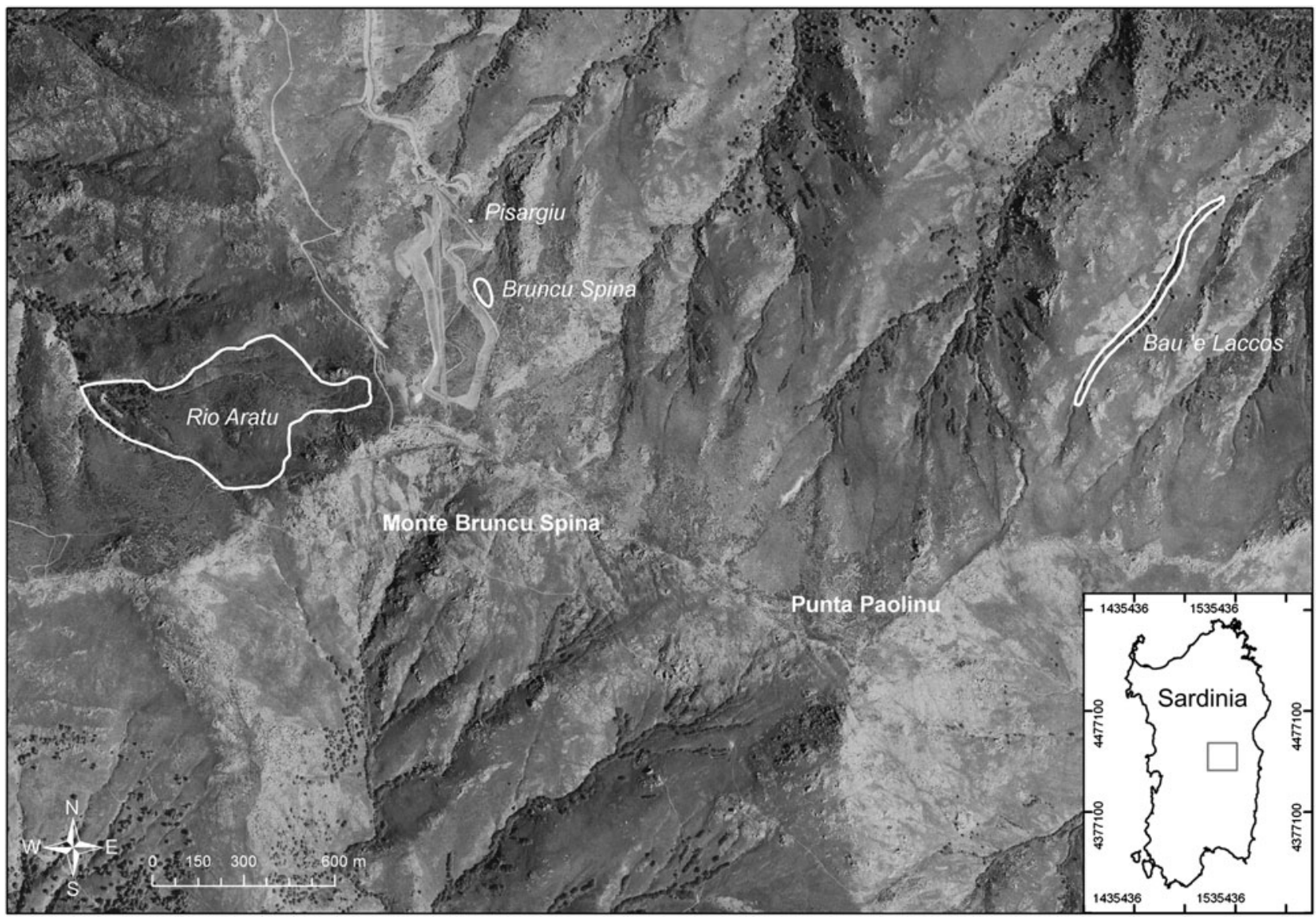

FIG. 1 The study area, showing the main peaks of the Gennargentu massif. The white lines and dot indicate the four areas where Lamyropsis microcephala has been found (Rio Aratu, Pisargiu, Bruncu Spina and Bau 'e Laccos). The rectangle on the inset indicates the location of the main figure in Sardinia.

(Table 1). Our field surveys during 2006-2009 in the two previously known localities found little variation in the extent of the populations between years (data not presented here). The vegetation community where $L$. microcephala grows is perennial grassland, with hemicryptophytes and cushion chamaephytes being dominant, characterized as the endemic Carici-Genistetea lobelioidis vegetation class (Pignatti et al., 1980). In the European Habitat Directive (DIR 92/43/EEC) this vegetation type is Endemic OroMediterranean heaths with gorse (code 4090) and the subtype Cyrno-Sardinian hedgehog-heaths (code 31.75). In the two larger localities (Rio Aratu and Bau 'e Laccos)

TABLE 1 The four sites where Lamyropsis microcephala has been located, with altitude range, mean slope (and range in parentheses), aspect and identified threats (IUCN, 2010b). Other threats (with ${ }^{\star}$ in the table) are coded in an earlier threats classification scheme (IUCN, 2007).

\begin{tabular}{|c|c|c|c|c|}
\hline Locality & Altitude (m) & Slope $\left(^{\circ}\right)$ & Aspect $\left(^{\circ}\right)$ & Threats \\
\hline Rio Aratu & $1450-1820$ & $20(5-35)$ & West (280) & $\begin{array}{l}1.3 \text { tourism \& recreation areas; } 2.3 .1 \text { nomadic } \\
\text { grazing; } 6.1 \text { recreational activities; } 2.4 \text { pathogens/ } \\
\text { parasites }^{\star}\end{array}$ \\
\hline Pisargiu & $1580-1590$ & 35 & North (5) & $\begin{array}{l}1.3 \text { tourism \& recreation areas; } 2.3 .1 \text { nomadic } \\
\text { grazing; } 2.4 \text { pathogens/parasites }{ }^{\star} ; 9.9 \text { restricted } \\
\text { range }^{*} ; 9.4 \text { inbreeding* }\end{array}$ \\
\hline Bruncu Spina & $1625-1637$ & 45 & North (355) & $\begin{array}{l}1.3 \text { tourism \& recreation areas; } 2.3 .1 \text { nomadic } \\
\text { grazing; } 2.4 \text { pathogens/parasites*; } 9.9 \text { restricted } \\
\text { range }^{*} ; 9.4 \text { inbreeding* }\end{array}$ \\
\hline Bau 'e Laccos† & $1450-1590$ & $15(10-30)$ & North (10) & $\begin{array}{l}1.3 \text { tourism \& recreation areas; } 2.3 .1 \text { nomadic } \\
\text { grazing; } 2.4 \text { pathogens/parasites* }\end{array}$ \\
\hline
\end{tabular}

†Localities newly discovered in this study 
TABLE 2 For each of the four localities of L. microcephala in 2009 the area, number of $2 \times 1 \mathrm{~m}$ monitoring plots, mean density of ramets, estimated population size, percentage of ramets reproductive, and mean number of capitula per reproductive ramet.

\begin{tabular}{|c|c|c|c|c|c|c|}
\hline Locality & Area $\left(\mathrm{m}^{2}\right)$ & $\begin{array}{l}\text { No. of } \\
\text { plots }\end{array}$ & $\begin{array}{l}\text { Mean density } \pm \\
\text { SD }\left(\text { ramets } \mathrm{m}^{-2}\right)^{1}\end{array}$ & $\begin{array}{l}\text { Estimated total } \\
\text { no. of ramets }\end{array}$ & $\begin{array}{l}\% \text { of ramets } \\
\text { reproductive }\end{array}$ & $\begin{array}{l}\text { Mean no. of } \\
\text { capitula per } \\
\text { reproductive } \\
\text { ramet } \pm \mathrm{SD}^{2}(\mathrm{n})\end{array}$ \\
\hline Rio Aratu & 240,000 & 55 & $8.29 \pm 14.3$ & $1,990,000$ & 58.8 & $2.59 \pm 1.7^{\mathrm{a}}(144)$ \\
\hline Pisargiu & 200 & 3 & $10.33 \pm 10.5$ & 2,066 & 52.3 & $1.98 \pm 1.5^{\mathrm{b}}(100)$ \\
\hline Bruncu Spina & 600 & 3 & $8.66 \pm 2.1$ & 5,196 & 59.2 & $2.46 \pm 1.8^{\mathrm{a}}(100)$ \\
\hline Bau 'e Laccos & 12,500 & 20 & $9.35 \pm 18.5$ & 116,875 & 56.7 & $2.69 \pm 1.8^{\mathrm{a}}(188)$ \\
\hline
\end{tabular}

${ }^{1}$ Test for differences in mean density: Kruskal-Wallis test $(\mathrm{df}=3, H=3.202 ; \mathrm{P}=0.362)$

${ }^{2}$ Test for differences in mean number of capitula per reproductive ramet: one-way ANOVA ( $\mathrm{df}=3, F=3.6263, \mathrm{P}=0.013$ ), followed by post hoc Duncans' test for pairwise analysis (values with the same letters are not different at $\mathrm{P}>0.05$ )

L. microcephala was found also in hygrophilous phytocoenosis of the endemic Caricion microcarpae alliance and, in Bau 'e Laccos, partly under Alnus glutinosa (L.) Gaertn. riparian woodlands.

The same threats were detected in all localities, with tourism and other outdoor activities the mean threats, followed by expansion of pastoral activities and nomadic grazing of sheep, cattle, horses and pigs (Table 1). Other detected pressures included natural threats and in particular the abundance of the parasitic plant Cuscuta spp..

The results of the plot surveys in 2009 are given in Table 2. The estimated number of ramets per locality varied considerably between the four localities but the mean densities $\left(8.29-10.33 \mathrm{~m}^{-2}\right)$ were not significantly different. The mean percentage of ramets that were reproductive did not differ greatly between localities (52.3-59.2\%). However, the mean number of capitula per reproductive ramet was 1.98-2.69 and was significantly lower at Pisargiu than at the other localities.

Table 3 presents the conservation measures adopted and proposed for $L$. microcephala. Those that we have already adopted are ex situ conservation (the seed collections) and formal education, and awareness and communications, with several lectures and seminars involving the local populace. We collected seed annually from 2006 to 2009 in Rio Aratu, from Pisargiu in 2006, 2007 and 2009, and from Bruncu Spina and Bau 'e Laccos in 2009 (Table 4). Depending on the total amount of seeds, sub-lots of each accession were made to create a base collection. Seeds were also sent to the Seed Conservation Department, Royal Botanic Gardens, Kew, Wakehurst Place, West Sussex, UK (Table 4).

Based on the extent of occurrence $\left(1.62 \mathrm{~km}^{2}\right)$, area of occupancy $\left(4 \mathrm{~km}^{2}\right)$, number of locations (one, sensu IUCN, 2008) and an inferred decline due to habitat loss and fragmentation of the original population, we confirmed the Red List categorization of Critically Endangered for L. microcephala, based on criteria Brab(i,ii,iii,v) + 2ab(i,ii,iii,v).

\section{Discussion}

Our discovery of two previously unknown localities for $L$. microcephala supports the hypothesis that these sites may constitute the remnants of a formerly larger population on the Bruncu Spina slopes in the area where the ski run was built in 1974, as suggested by herbarium specimen collected in 1972 on the north slope of this mountain at $1,750 \mathrm{~m}$ (Diana Corrias, 1977). The major threats to L. microcephala are habitat loss from the expansion of infrastructure for tourism, and grazing. Tourism and recreational activities

TABLE 3 Conservation measures carried out in this study, or proposed, for L. microcephala. Conservation actions are coded following IUCN (2010a).

\begin{tabular}{lll}
\hline Conservation action & Adopted & Proposed \\
\hline $\begin{array}{l}\text { 1. Land/water protection } \\
\text { 2. Land/water management }\end{array}$ & $\begin{array}{l}1.1 \text { Site/area protection } \\
\text { 2.1 Site/area management } \\
\text { 3. Species management }\end{array}$ & 2.3 Habitat \& natural process restoration \\
4. Education \& awareness & 3.4 Ex situ conservation & \\
5. Law \& policy & 4.1 Formal education & \\
& 4.3 Awareness \& communications & \\
& & 5.1 .3 Legislation at sub-national level \\
& & 5.1 .4 Legislation at municipality level \\
\end{tabular}

${ }^{\star}$ The conservation measures reported in Camarda (2006). 
TABLE 4 Seed lots of L. microcephala stored in the Sardinian Germplasm Bank and sent to the Seed Conservation Department, Kew.

\begin{tabular}{|c|c|c|c|c|c|c|}
\hline $\begin{array}{l}\text { Collection dates } \\
\text { (by locality) }\end{array}$ & $\begin{array}{l}\text { No. of sampled } \\
\text { ramets }\end{array}$ & $\begin{array}{l}\text { No. of } \\
\text { seeds }\end{array}$ & $\begin{array}{l}\text { Black-box } \\
\text { collection }\end{array}$ & $\begin{array}{l}\text { Check-up } \\
\text { collection }\end{array}$ & $\begin{array}{l}\text { Active } \\
\text { collection }\end{array}$ & Kew duplicata \\
\hline \multicolumn{7}{|l|}{ Rio Aratu } \\
\hline 12 Aug. $2006^{*}$ & $100^{*}$ & $906^{*}$ & 406 & 500 & & \\
\hline 17-18 Aug. 2007 & 500 & 8,235 & 3,435 & 500 & 1,300 & 3,000 \\
\hline 23 Aug. 2008 & 50 & 4,303 & 2,500 & 500 & 1,303 & \\
\hline 19 Aug. 2009 & 30 & 1,956 & 1,400 & 500 & & \\
\hline \multicolumn{7}{|l|}{ Pisargiu } \\
\hline 20 Aug. $2006^{*}$ & $30^{*}$ & $26^{*}$ & 26 & & & \\
\hline 17 Aug. 2007 & 50 & 368 & 368 & & & \\
\hline 31 Aug. 2009 & 50 & 1,054 & 554 & 500 & & \\
\hline \multicolumn{7}{|l|}{ Bruncu Spina } \\
\hline 20 Aug. 2009 & 25 & 250 & 250 & & & \\
\hline \multicolumn{7}{|l|}{ Bau 'e Laccos } \\
\hline 20 Aug. 2009 & 25 & 1,262 & 762 & 500 & & \\
\hline
\end{tabular}

${ }^{\star}$ Reported in Bacchetta et al. (2007)

are the main threat to ecosystems in the Mediterranean area (Allen, 2001) and typically lead to habitat fragmentation (Gibbs, 2001).

Although the effects of trampling on Mediterranean endemic plants has been rarely investigated, there have been several studies of the effects of grazing. Overgrazing affects plant density and survival rate, flowering season and recruitment rate (Lavergne et al., 2005; Ramula, 2008; Sletvold \& Grindeland, 2008), whereas if grazing is regulated or limited to certain seasons it improves population growth (Bullock et al., 1994; Ehrlén et al., 2005; Picó et al., 2008). A positive effect of regulated grazing has been reported for rhizomatous plants (Bullock et al., 1994; Jongejans et al., 2008). Nevertheless, as a precautionary measure, grazing and the tourism activities should be regulated in the four known localities of $L$. microcephala, and no new pathways opened (Table 3 ).

Habitat fragmentation increases extinction risk for rare species (Holsinger, 2000; Matthies et al., 2004; Schleuning \& Matthies, 2009), interferes with distribution, fitness and seedling recruitment (Lienert, 2004; Kolb \& Diekmann, 2005; Benito et al., 2009; Vere de et al., 2009), reduces the number of breeding individuals and gene flow (Dudash \& Fenster, 2000) and pollination efficiency (Duncan et al., 2004). Although G. Bacchetta et al. (unpubl. data) detected a moderate level of genetic diversity in the populations of L. microcephala at Rio Aratu and Pisargiu, the low number of capitula per ramet that we found is probably related to the small population size, as demonstrated in several studies (Fischer \& Matthies, 1998; Oostermeijer et al., 1998).

The discovery of $L$. microcephala in two new localities has enlarged the previously reported EOO $\left(0.32 \mathrm{~km}^{2}\right.$; Bacchetta et al., 2008). Nevertheless this has not altered the current categorization of the species as Critically Endangered, although the criteria are different. Our implementation of ex situ conservation measures for
L. microcephala continues the work started by Bacchetta et al. (2007). Considering the significant degree of genetic differentiation between the two historical L. microcephala localities (G. Bacchetta et al., unpubl. data) the creation of a black-box seed collection for all four localities now known will ensure the conservation of the genetic variability of this threatened species. The seeds collected could be used for future reinforcement, restoration or reintroduction of the species in suitable areas of the Gennargentu massif.

This study of a Critically Endangered extremely narrow endemic plant of the Mediterranean area, together with population genetic studies in progress, is the first part of a long-term integrated conservation programme for the species. The approach described here could serve as a model for determining conservation status and developing conservation strategies for other narrowly distributed, threatened species for which little is known of their distribution and reproductive biology.

\section{Acknowledgements}

This research was funded by RAS-Assessorato Difesa Ambiente. The support of the Millennium Seed Bank Project (Seed Conservation Department, Royal Botanic Gardens, Kew) is gratefully acknowledged. We thank T. Ulian and A. Congiu for help with fieldwork.

\section{References}

Allen, H.D. (2001) Mediterranean Ecogeography. Pearson Education, Harlow, UK.

ARrigoni, P.V. (1974) I tipi di vegetazione e le entità floristiche in pericolo di estinzione nella Sardegna Centrale. Biologia Contemporanea, 3, 97-104.

Bacchetta, G., Fenu, G., Mattana, E. \& Ulian, T. (2007) Preliminary results on the conservation of Lamyropsis microcephala (Moris) Dittrich \& Greuter (Compositae), a threatened endemic 
species of the Gennargentu massif, Sardinia (Italy). Flora

Montiberica, 36, 6-14.

Bacchetta, G., Fenu, G., Mattana, E. \& Ulian, T. (2008) Lamyropsis microcephala (Moris) Dittrich \& Greuter. Informatore Botanico Italiano, 40 (Suppl. 1), 84-86.

Bakkenes, A., Alkemade, J.R.M., Ihle, F., Leemans, R. \& Latour, J.B. (2002) Assessing effects of forecasted climate change on the diversity and distribution of European higher plants for 2050. Global Change Biology, 8, 390-407.

Benito, B.M., Martínez-Ortega, M.M., Muñoz, L.M., Lorite, J. \& PeÑas, J. (2009) Assessing extinction-risk of endangered plants using species distribution models: a case study of habitat depletion caused by the spread of greenhouses. Biodiversity and Conservation, 18, 2509-2520.

Bullock, J.M., Hill, B.C. \& Silvertown, J. (1994) Demography of Cirsium vulgare in a grazing experiment. Journal of Ecology, 82, 101-111.

CAMARDA, I. (2006) Lamyropsis microcephala. In IUCN Red List of Threatened Species v. 2009.2. Http://www.iucnredlist.org [accessed 25 January 2010].

Conti, F., Manzi, A. \& Pedrotti, F. (1992) Libro rosso delle Piante d'Italia. Ministero Ambiente, WWF Italia, Società Botanica Italiana, Rome, Italy.

Conti, F., Manzi, A. \& Pedrotti, F. (1997) Liste rosse regionali delle piante d'Italia. Università degli Studi di Camerino, Camerino, Italy.

Davis, M.B. \& Shaw, R.G. (2001) Range shifts and adaptive responses to quaternary climate change. Science, 292, 673-679.

Diana Corrias, S. (1977) Le piante endemiche della Sardegna: 6-7. Bollettino Società Sarda di Scienze Naturali, 16, 287-294.

DudAsh, M.R. \& Fenster, C.B. (2000) Inbreeding and outbreeding depression in fragmented populations. In Genetics, Demography and Viability of Fragmented Populations (eds A.G. Young \& G.M. Clarke), pp. 35-53. Cambridge University Press, Cambridge, UK.

Duncan, D.H., Nicotra, A.B., Wood, J.T. \& Cunningham, S.A. (2004) Plant isolation reduces outcross pollen receipt in a partially self-compatible herb. Journal of Ecology, 92, 977-985.

Ehrlén, J., Syrjänen, K., Leimu, R., García, M.B. \& Lethilä, K. (2005) Land use and population growth of Primula veris: an experimental demographic approach. Journal of Applied Ecology, $42,317-325$

Fischer, M. \& Matthies, D. (1998) Effects of population size on performance in the rare plant Gentianella germanica. Journal of Ecology, 86, 195-204.

Francisco-Ortega, J., Santos-Guerra, A., Kim, S.C. \& Crawford, D.J. (2000) Plant genetic diversity in the Canary Islands: a conservation perspective. American Journal of Botany, 87, 909-919.

GBIF (2011) Global Biodiversity Information Facility. Http:// www.gbif.org [accessed 2 February 2011].

Gibis, J.P. (2001) Demography versus habitat fragmentation as determinants of genetic variation in wild populations. Biological Conservation, 100, 15-20.

Gottfried, M., Pauli, H., Reiter, K. \& Grabeherr, G. (1999) A fine-scaled predictive model for changes in species distribution patterns of high mountain plants induced by climate warming. Diversity and Distributions, 5, 241-251.

Grammont De, P.C. \& Cuarón, A.D. (2006) An evaluation of threatened species categorization systems used on the American continent. Conservation Biology, 20, 14-27.

GSPC (Global Strategy for Plant Conservation) (2008) Http:// www.cbd.int/gspc/ [accessed 24 June 2009].

Hoffman, M., Brooks, T.M., da Fonseca, G.A.B., Gascon, C., Hawkins, A.F.A., James, R.E. et al. (2008) Conservation planning and the IUCN Red List. Endangered Species Research, 6, $113-125$.

Holsinger, K.E. (2000) Demography and extinction in small populations. In Genetics, Demography and Viability of Fragmented Populations (eds A.G. Young \& G.M. Clark), pp. 55-74. Cambridge University Press, Cambridge, UK.

Iriondo, J.M. \& Pérez, C. (1999) Propagation from seeds and seed preservation. In A Colour Atlas of Plant Propagation and Conservation (ed. B.G. Bowes), pp. 46-57. Manson Publishing, London, UK.

IUCN (2001) IUCN Red List categories v. 3.1. IUCN Species Survival Commission Re-introduction Specialist Group, IUCN, Gland, Switzerland, and Cambridge, UK.

IUCN (2007) Threats Authority File v. 2.1. Http://www.iucnredlist. org/info/major_threats [accessed 28 June 2007]

IUCN (2008) Guidelines for Using the IUCN Red List Categories and Criteria v. 7.o. Standards and Petitions Working Group of the IUCN Species Survival Commission Biodiversity Assessments Sub-Committee, August 2008.

IUCN (2010a) Conservation Actions Classification Scheme v. 2.o. Http://www.iucnredlist.org/technical-documents/classificationschemes/conservation-actions-classification-scheme-ver2 [accessed 25 January 2010].

IUCN (2010b) Threats Classification Scheme v. 3.o. Http:// www.iucnredlist.org/technical-documents/classification-schemes/ threats-classification-scheme-ver3 [accessed 25 January 2010].

Iverson, L.R. \& Prasad, A.M. (1998) Predicting abundance of 80 tree species following climate change in the Eastern United States. Ecological Monographs, 68, 465-485.

Jongejans, E., de Vere, N. \& Kroon de, H. (2008) Demographic vulnerability of the clonal and endangered meadow thistle. Plant Ecology, 198, 225-240.

Kazakisv, G., Ghosn, D., Vogiatzakis, I.N. \& Papanastasis, V.P. (2007) Vascular plant diversity and climate change in the alpine zone of the Lefka Ori, Crete. Biodiversity and Conservation, $16,1603-1615$.

Kolb, A. \& Diekmann, M. (2005) Effects of life-history traits on responses of plant species to forest fragmentation. Conservation Biology, 19, 929-938.

LANDE, R. (1988) Genetic and demography in biological conservation. Science, 241, 1455-1460.

Lavergne, S., Debussche, M. \& Thompson, J.D. (2005) Limitations on reproductive success in endemic Aquilegia viscosa (Ranunculaceae) relative to its widespread congener Aquilegia vulgaris: the interplay of herbivory and pollination. Oecologia, 142, 212-220.

Lienert, J. (2004) Habitat fragmentation effects on fitness of plant populations-a review. Journal for Nature Conservation, 12, $53-72$.

Mattana, E., Daws, M.I. \& Bacchetta, G. (2009) Seed dormancy and germination ecology of Lamyropsis microcephala: a mountain endemic species of Sardinia (Italy). Seed Science and Technology, 37, 491-497.

Matthies, D., Bräuer, I., Maibom, W. \& Tscharntke, T. (2004) Population size and the risk of local extinction: empirical evidence from rare plants. Oikos, 105, 481-488.

MÉdail, F. \& Diadema, K. (2009) Glacial refugia influence plant diversity patterns in the Mediterranean Basin. Journal of Biogeography, 36, 1333-1345.

Montmollin De, B. \& Strahm, W. (eds) (2005) The Top 50 Mediterranean Island Plants: Wild Plants at the Brink of Extinction, and What is Needed to Save Them. IUCN/Species Survival Commission Mediterranean Islands Plant Specialist Group. IUCN, Gland, Switzerland, and Cambridge, UK. 
Myers, N., Mittermeier, R.A., Mittermeier, C.G., Da Fonseca, G.A.B. \& Kents, J. (2000) Biodiversity hotspots for conservation priorities. Nature, 403, 853-858.

Oostermeijer, J.G., Luijten, S.H., Krenova, Z.V. \& Den Nijis, H.M.C. (1998) Relationships between population and habitat characteristics and reproduction of rare Gentiana pneumonanthe. Conservation Biology, 12, 1942-1953.

Pickering, C., Wendy, H. \& Ken, G. (2008) Vascular plant diversity and climate change in the alpine zone of the Snowy Mountains, Australia. Biodiversity and Conservation, 17, 1627-1644.

Picó, F.X., Quintana - Ascencio, P.F., Mildénd, M., Ehrlén, J. \& Pfingsten, I. (2009) Modelling the effects of genetics and habitat on the demography of a grassland herb. Basic and Applied Ecology, 10, 122-130.

Pignatti, E., Pignatti, S., Nimis, P. \& Avanzini, A. (1980) La vegetazione ad arbusti spinosi emisferici: contributo alla interpretazione delle fasce di vegetazione delle alte montagne dell'Italia mediterranea. CNR Aq/1/79, Rome, Italy.

Pignatti, S., Menegoni, S. \& Giacanelli, V. (2001) Liste rosse e blu della flora italiana. ANPA, Rome, Italy.

Planta Europa (2008) A Sustainable Future for Europe: The European Strategy for Plant Conservation 2008-2014. Plantlife International, Salisbury, UK, and the Council of Europe, Strasbourg, France.

Ramula, S. (2008) Population dynamics of a monocarpic thistle: simulated effects of reproductive timing and grazing of flowering plants. Acta Oecologica, 33, 231-239.
Rodrigues, A.S.L., Pilgrim, J.D., Lamoreux, J.L., Hoffmann, M. \& BRooks, T.M. (2006) The value of the IUCN Red List for conservation. Trends in Ecology and Evolution, 21, 71-76.

Rossi, G. \& Gentili, R. (2008) A partnership project for a new Red List of the Italian Flora. Plant Biosystems, 142, 302-304.

Schleuning, M. \& Matthies, D. (2009) Habitat change and plant demography: assessing the extinction risk of a formerly common grassland perennial. Conservation Biology, 23, 174-183.

Sharrock, S. \& Jones, M. (2009) Conserving Europe's Threatened Plants: Progress Towards Target 8 of the Global Strategy for Plant Conservation. Botanic Gardens Conservation International, Richmond, UK.

Sletvold, N. \& Grindeland, J.M. (2008) Floral herbivory increases with inflorescence size and local plant density in Digitalis purpurea. Acta Oecologica, 34, 21-25.

Vere de, N., Jongejans, E., Plowman, A. \& Williams, E. (2009) Population size and habitat quality affect genetic diversity and fitness in the clonal herb Cirsium dissectum. Oecologia, 159, 59-68.

\section{Biographical sketches}

Giuseppe Fenu has a particular interest in conservation of the endemic and threatened plants of Sardinia. Efisio Mattana is interested in ex situ conservation and germination ecophysiology of the endemic flora of Sardinia. Gianluigi Bacchetta carries out geobotanical analyses in the western Mediterranean area. 